\title{
Potassium octatitanate fibers (TISMO) induce pleural mesothelial cell reactions with iron accumulation in female $\mathrm{A} / \mathrm{J}$ mice
}

\author{
MASANAO YOKOHIRA, NOZOMI HASHIMOTO, KEIKO YAMAKAWA, SATOSHI SUZUKI, \\ KOUSUKE SAOO, TOSHIYA KUNO and KATSUMI IMAIDA
}

Onco-Pathology, Department of Pathology and Host-Defense, Kagawa University, Kagawa 761-0793, Japan

Received February 22, 2010; Accepted May 11, 2010

DOI: 10.3892/ol_00000104

\begin{abstract}
It is crucial to develop therapeutic approaches for malignant mesothelioma, as well as to obtain information involving the possible mechanism involved in the development of mesothelioma. Subsequently, thoracotomy was performed to infuse test particles directly into the thoracic cavity of $\mathrm{A} / \mathrm{J}$ mice. Fiber-shaped particles of potassium octatitanate (TISMO) and granular-shaped micro- and nano-size order particles of titanium dioxide $\left(\mathrm{TiO}_{2}\right)$ were employed $(1.5 \mathrm{mg}$ in $0.2 \mathrm{ml}$ saline/mouse). The experiment was terminated after 21 weeks to assess responses. Only the fiber-shaped TISMO, morphologically similar to asbestos, induced a severe reaction of the pleura. A number of TISMO fibers were observed in the alveoli, indicating penetration through the pleura. Following Berlin blue staining, positive spots were observed around the TISMO fibers, indicative of iron. These positive spots corresponded with cells that immunostained positively for calretinin, a marker of mesothelial cells. Similar observations were reported for asbestos-induced mesothelioma. The present study showed that only fiber-shaped TISMO induced severe reactions of the mesothelium in the pleura, and these involved iron accumulation derived from endogenous sources. The results indicate that the risk of mesothelial cell reaction does not depend on particle size, but may depend on shape.
\end{abstract}

\section{Introduction}

The incidence of malignant pleural mesothelioma is on the increase and is anticipated to increase further in future decades as a result of widespread exposure to asbestos particularly in unprotected countries $(1,2)$. Epidemiologically, analyses using an age-cohort model in Japan showed that

Correspondence to: Professor Katsumi Imaida, Onco-Pathology, Department of Pathology and Host-Defence, Faculty of Medicine, Kagawa University, 1750-1, Ikenobe, Miki-cho, Kita-gun, Kagawa 761-0793, Japan

E-mail: imaida@med.kagawa-u.ac.jp

Key words: potassium octatitanate, lung, mesothelioma, iron, A/J mouse, titanium dioxide there may be approximately 100,000 deaths due to pleural mesothelioma in the next 40 years (3). Based on US mesothelioma incidence data from 1973 to 2000, it was estimated that the total number of male mesothelioma cases in 20032054 will reach approximately 71,000 (4). Thus, it is crucial to develop treatment modalities for the therapy of malignant mesothelioma, and an appropriate animal model is necessary for this purpose. Reports exist on peritoneal mesothelioma induction by chemicals or fibers in conventional rats (5-8) or pleural mesotheliomas in genetically modified animals such as the p53 knockout mouse (9). Lardinois et al also reported the efficacy of the intrapleural application of cisplatin in an immune-competent rat model inoculated with mesothelioma cells (10). Since pleural malignant mesothelioma is the most common form of mesothelioma in humans (11), a bioassay model featuring similar lesions in otherwise normal animals would be optimal. However, to our knowledge no report of pleural mesothelioma in experimental wild-type animals using direct infusion of particles currently exists. In our previous study, $0.2 \mathrm{ml}$ of polymer gel was infused directly into the left cavity of the thorax by thoracotomy to occupy a certain thoracic cavity volume and to examine the influence of physical pulmonary collapse. We demonstrated that a pronounced mesothelial cell reaction to the infused polymer was evident on the left lung surfaces and parietal pleura (12).

In the present study, thoracotomy was performed to allow for the infusion of particles directly into the thoracic cavity of $\mathrm{A} / \mathrm{J}$ mice. In order to assess differences in the reaction depending on the shape of the infused particles, fiber-shaped potassium octatitanate (TISMO) and granular-shaped microand nano-size order titanium dioxide $\left(\mathrm{TiO}_{2}\right)$ were employed as test materials. To contribute to the mechanistic analysis, iron staining with Berlin blue and immunostaining for calretinin were also performed.

\section{Materials and methods}

Chemicals. Potassium octatitanate fibers, trade name TISMO, and the chemical formula $\mathrm{K}_{2} \mathrm{O} \cdot \mathrm{nTiO}_{2}$, were supplied by Otsuka Chemical Co., Ltd. (Osaka, Japan) with dimensions mostly $<50 \mu \mathrm{m}$ in length and $<2 \mu \mathrm{m}$ in width [Fig. 2; scanning electron microscope (SEM) image, JSM-6400 (Joel Ltd., Tokyo, Japan), at a magnification x3,000]. Granular-shaped $\mathrm{TiO}_{2}$ with particle diameters of $<5 \mu \mathrm{m}$ (Rutile form, lot. TCG4139) 


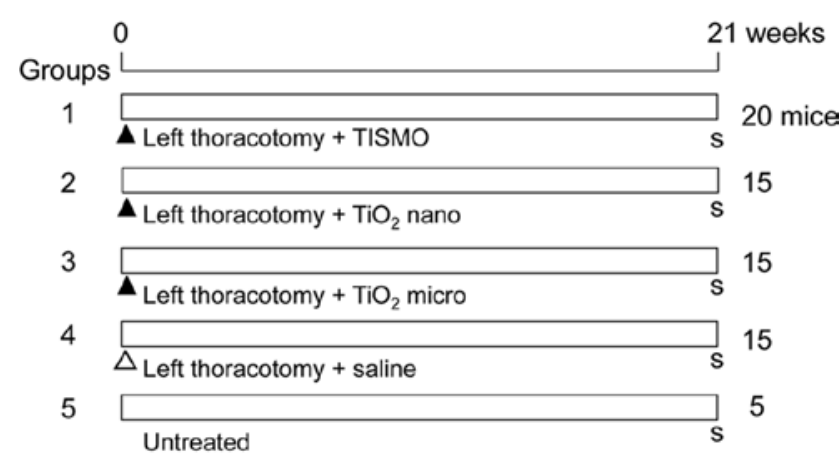

Figure 1. Experimental design. A total of 70 mice at 7 weeks of age were employed. At week 0, Groups 1-4 underwent a left thoracotomy and were administered $1.5 \mathrm{mg}$ of particles suspended in $0.2 \mathrm{~m}$ saline: $\mathbf{\Lambda}$, TISMO (Group 1), $\mathrm{TiO}_{2}$ nano (Group 2), $\mathrm{TiO}_{2}$ micro (Group 3) or $\Delta$, vehicle alone (Group 4, saline control group). Group 5 is the untreated group. All groups were sacrificed (S) at week 21.

( $\mathrm{TiO}_{2}$ micro) and $~ 80 \mathrm{~nm}$ (lot. DPN0960) $\left(\mathrm{TiO}_{2}\right.$ nano) were purchased from Wako Pure Chemical Industries, Ltd. (Osaka, Japan). The particles were all suspended in saline (Otsuka isotonic sodium chloride solution; Otsuka Pharmaceutical Factory, Inc., Tokushima, Japan).

Animals. Female A/J mice (5 weeks old), purchased from Shizuoka Laboratory Animal Center (Shizuoka, Japan), were maintained in the Division of Animal Experimentation, Life Science Research Center, Kagawa University, according to the Institutional Regulations for Animal Experiments. The protocols of the experiments were approved by the Animal Care and Use Committee of Kagawa University. The animals were housed in polycarbonate cages with white wood chips for bedding and given free access to drinking water and a basal diet, Oriental MF (Oriental Yeast Co., Ltd., Tokyo, Japan), under controlled conditions of humidity $(60 \pm 10 \%)$, lighting (12-h light/dark cycle) and temperature $\left(24 \pm 2^{\circ} \mathrm{C}\right)$. The experiments were started after a 2 -week acclimatization period.

Experimental design and tissue preparation. Fig. 1 shows the design for the experiment. A total of 70 mice at 7 weeks of age were divided into 5 groups of 20 (Group 1), 15 (Groups 2, 3 and 4) and 5 (Group 5) mice. At the beginning of the experiment, the 65 mice of Groups 1-4 underwent a left thoracotomy and were administered $1.5 \mathrm{mg}$ of TISMO particles (Group 1), $\mathrm{TiO}_{2}$ nano (Group 2), $\mathrm{TiO}_{2}$ micro (Group 3) (all suspended in $0.2 \mathrm{ml}$ saline) or the vehicle (Group 4, saline control group). Each mouse was administered intraperitoneally $0.2 \mathrm{ml}$ pentobarbital sodium (Nembutal, Dainippon Sumitomo Pharma Co., Ltd., Osaka, Japan) with a 10 times dilution (0.06-0.1 $\mathrm{ml} / 10 \mathrm{~g}$ body weight). Under deep anesthesia, a skin incision $(\sim 7 \mathrm{~mm})$ was performed on the left axilla. After confirmation of the location of the thoracic wall, a thoracotomy was completed with an incision $(\sim 5 \mathrm{~mm})$ between the ribs. The left lung was observed directly through this open hole, and atelectasis was confirmed. Following test particle infusion into the left thoracic cavity, the skin was clipped together to close the thorax. The experiment was terminated after 21 weeks, and all of the groups were sacrificed under deep anesthesia.

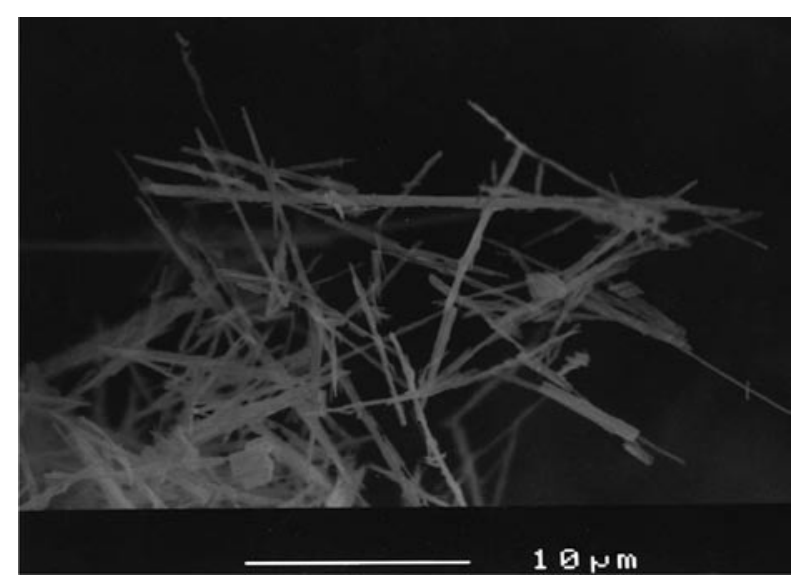

Figure 2. Scanning electron microscope image of fiber-shaped TISMO. Magnification, x3,000.

At autopsy, the lungs, liver and kidneys were removed. The lungs were initially weighed, followed by the trachea and heart. The organs were then rinsed and infused with $10 \%$ neutral-buffered formalin. The lung weight was calculated by subtraction of the trachea and heart weight. The organs were immersed in 10\% neutral-buffered formalin for 1 week, and sections were routinely processed for embedding in paraffin for histopathological examination of hematoxylin and eosinstained sections. Sections were also prepared for special staining with Berlin blue to detect iron accumulation and immunostaining of calretinin to identify mesothelial cells (13).

Immunostaining analysis. The lungs were immunostained by the avidin-biotin complex (ABC) method, and all staining processes from deparaffinization to counterstaining with hematoxylin were performed automatically using the Ventana Discovery ${ }^{\mathrm{TM}}$ staining system (Ventana Medical Systems, AZ, USA). Anti-mouse calretinin monoclonal antibody, clone 5A5, purchased from Novocastra Laboratories Ltd. (Newcastle upon Tyne, UK) was employed at a 1:100 dilution.

Statistical analysis. The body and organ weight data were analyzed by the Tukey-Kramer test (multi-comparison test) and the incidences of lung lesions by the Chi-square test.

\section{Results}

Two mice died (1 each in Groups 2 and 3) following thoracotomy. The general condition in all of the groups consisted of no marked changes during the experimental period. Final body and organ weights are shown in Table I. The body weights of Group 1 were significantly greater than those of Group 4. The absolute weights of the lungs of Group 1 and the livers of Group 5 demonstrated significant differences in comparison to Group 4. However, the relative weights were similar, without significant variation.

Grossly, the infused TISMO, $\mathrm{TiO}_{2}$ micro- or $\mathrm{TiO}_{2}$ nanoparticles formed discrete masses in the cavity of the chest. Severe adhesions around the lung to the thorax were observed in the TISMO-treated group (Group 1) (Fig. 3), while less or no adhesion was evident in the $\mathrm{TiO}_{2}$ nano- or $\mathrm{TiO}_{2}$ micro- 
Table I. Body and organs weights of the mice.

\begin{tabular}{|c|c|c|c|c|c|}
\hline $\begin{array}{l}\text { Groups } \\
\text { Left thoracotomy } \\
\text { Treatment }\end{array}$ & $\begin{array}{c}1(\mathrm{n}=20) \\
+ \\
\text { TISMO }\end{array}$ & $\begin{array}{c}2(\mathrm{n}=14) \\
+ \\
\mathrm{TiO}_{2} \text { nano }\end{array}$ & $\begin{array}{c}3(\mathrm{n}=14) \\
+ \\
\mathrm{TiO}_{2} \text { micro }\end{array}$ & $\begin{array}{c}4(\mathrm{n}=15) \\
+ \\
\text { Saline }\end{array}$ & $\begin{array}{c}5(\mathrm{n}=5) \\
- \\
\text { Untreated }\end{array}$ \\
\hline Body weight (g) & $32.3 \pm 7.7^{\mathrm{a}}$ & $25.0 \pm 2.1$ & $26.1 \pm 2.2$ & $27.4 \pm 3.6$ & $32.5 \pm 4.2$ \\
\hline $\begin{array}{l}\text { Lungs } \\
\text { Absolute (g) } \\
\text { Relative (\%) }\end{array}$ & $\begin{array}{l}0.28 \pm 0.04^{a} \\
0.91 \pm 0.26\end{array}$ & $\begin{array}{l}0.19 \pm 0.03 \\
0.76 \pm 0.13\end{array}$ & $\begin{array}{l}0.19 \pm 0.02 \\
0.73 \pm 0.08\end{array}$ & $\begin{array}{l}0.21 \pm 0.03 \\
0.76 \pm 0.11\end{array}$ & $\begin{array}{l}0.23 \pm 0.02 \\
0.70 \pm 0.10\end{array}$ \\
\hline $\begin{array}{l}\text { Liver } \\
\text { Absolute (g) } \\
\text { Relative (\%) }\end{array}$ & $\begin{array}{l}1.20 \pm 0.16 \\
3.85 \pm 0.76\end{array}$ & $\begin{array}{l}1.10 \pm 0.22 \\
4.43 \pm 1.01\end{array}$ & $\begin{array}{l}1.09 \pm 0.09 \\
4.17 \pm 0.34\end{array}$ & $\begin{array}{l}1.18 \pm 0.14 \\
4.33 \pm 0.38\end{array}$ & $\begin{array}{l}1.44 \pm 0.15^{\mathrm{a}} \\
4.44 \pm 0.32\end{array}$ \\
\hline $\begin{array}{l}\text { Kidneys } \\
\text { Absolute (g) } \\
\text { Relative (\%) }\end{array}$ & $\begin{array}{l}0.29 \pm 0.04 \\
0.93 \pm 0.18\end{array}$ & $\begin{array}{l}0.26 \pm 0.04 \\
1.03 \pm 0.18\end{array}$ & $\begin{array}{l}0.25 \pm 0.02 \\
0.98 \pm 0.10\end{array}$ & $\begin{array}{l}0.28 \pm 0.02 \\
1.02 \pm 0.10\end{array}$ & $\begin{array}{l}0.31 \pm 0.03 \\
0.97 \pm 0.10\end{array}$ \\
\hline
\end{tabular}

${ }^{\mathrm{a}}<0.05$ vs. Group 4. TISMO, potassium octatitanate; $\mathrm{TiO}_{2}$, titanium dioxide.

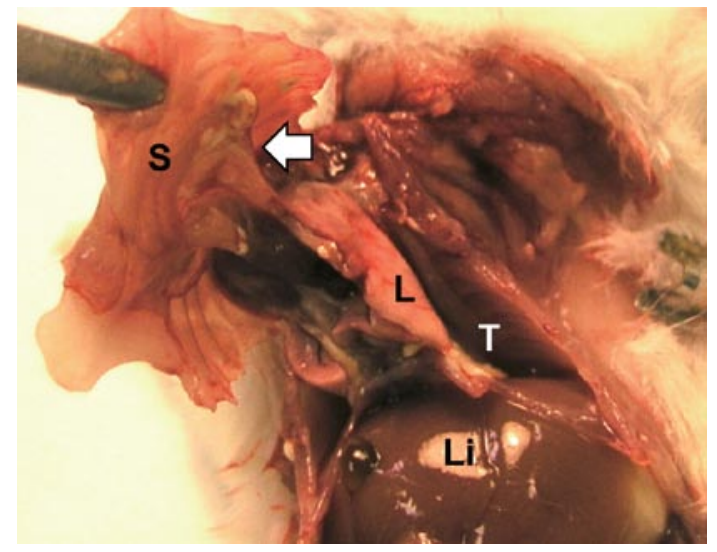

Figure 3. Gross findings for the TISMO-treated group (Group 1) at week 21. Severe adhesions (arrow) around the left lung (L) to the thorax were observed. $\mathrm{Li}$, liver; $\mathrm{S}$, sternal bone; $\mathrm{T}$, thoracic cavity. treated groups (Groups 2 and 3, respectively). The control groups (Groups 4 and 5) were without inflammatory lesions.

Histopathologically, pleural thickening was observed after TISMO (Group 1) (Fig. 4A), but not $\mathrm{TiO}_{2}$ nano or $\mathrm{TiO}_{2}$ micro treatment (Groups 2 and 3, respectively) (Fig. 4B and C). In the TISMO-treated group (Group 1), fibers were detected, not only in areas of pleural thickening, but also within alveoli (Fig. 4D). However, inflammatory reactions were limited to the pleura. Table II shows the incidences of lung lesions. In the TISMO-treated group (Group 1), pleural thickening and particles in the alveoli were detected at significantly greater incidences than in the other groups. In the particle-treated groups (Groups 1, 2 and 3), deposits were observed in the lymph nodes around the lungs. In the lungs, adenomas were noted in all of the groups, but without significant intergroup differences. Positive spots of Berlin blue staining (Fig. 5B and E)

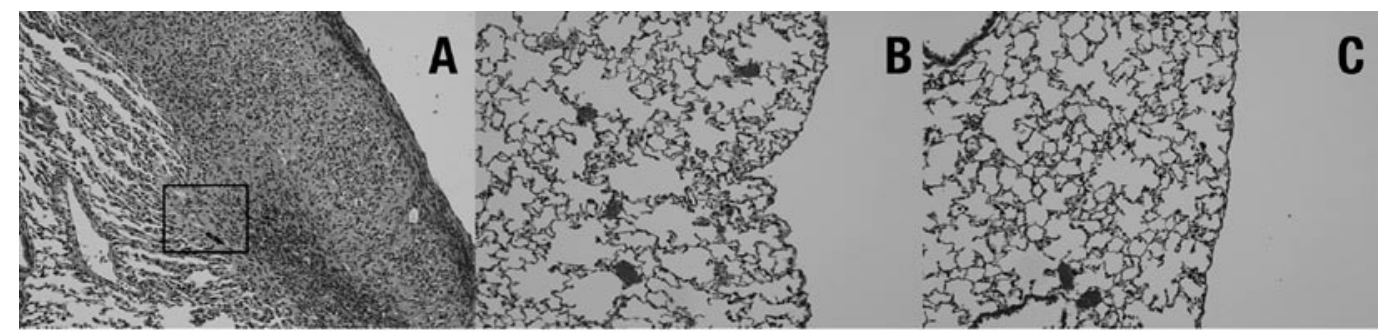

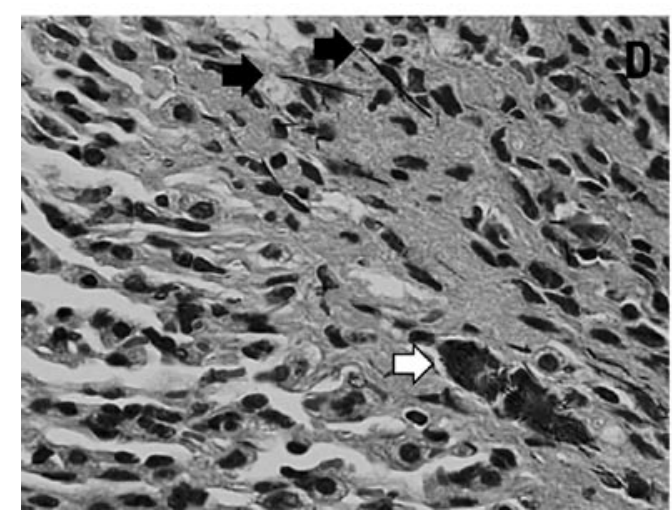

Figure 4. Histopathological findings at week 21. (A) TISMO-treated group (Group 1). (B) $\mathrm{TiO}_{2}$ nano- (Group 2) and (C) $\mathrm{TiO}_{2}$ micro-treated groups (Group 3). (D) High magnification of TISMO-treated group (Group 1). Pleural thickening was observed in the (A) TISMO-treated group (Group 1), but not in the (B and $\mathrm{C}$ ) $\mathrm{TiO}_{2}$ nano- or $\mathrm{TiO}_{2}$ micro-treated groups (Groups 2 and 3). TISMO fibers were detected in an area of pleural thickening and in alveoli. (D) Black arrows, TISMO fibers; white arrow, agglutinated TISMO fibers. 
Table II. Histopathological findings of the lung.

\begin{tabular}{|c|c|c|c|c|c|}
\hline Groups & $1(n=20)$ & $2(n=14)$ & $3(n=14)$ & $4(n=15)$ & $5(n=5)$ \\
\hline Left thoracotomy & + & + & + & + & - \\
\hline Treatment & TISMO & $\mathrm{TiO}_{2}$ nano & $\mathrm{TiO}_{2}$ micro & Saline & Untreated \\
\hline \multicolumn{6}{|l|}{ Incidence $\%$} \\
\hline Pleural thickening & $100.0^{\mathrm{a}}(20 / 20)$ & $7.1 \quad(1 / 14)$ & $14.3 \quad(2 / 14)$ & $0.0(0 / 15)$ & $0.0(0 / 5)$ \\
\hline Particles in the alveoli & $100.0^{\mathrm{a}}(20 / 20)$ & $0.0 \quad(0 / 14)$ & $0.0 \quad(0 / 14)$ & $0.0(0 / 15)$ & $0.0(0 / 5)$ \\
\hline Particles in the lymph nodes & $75.0^{\mathrm{b}}(15 / 20)$ & $92.9^{b}(13 / 14)$ & $100.0^{\mathrm{b}}(14 / 14)$ & $0.0(0 / 15)$ & $0.0(0 / 5)$ \\
\hline Adenoma (lung) & $5.1 \quad(3 / 20)$ & $35.7 \quad(5 / 14)$ & $7.1 \quad(1 / 14)$ & $13.3(2 / 15)$ & $20.0(1 / 5)$ \\
\hline
\end{tabular}

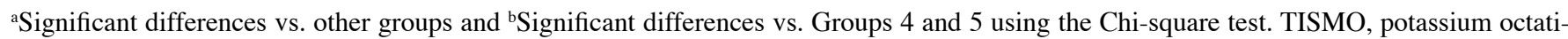
tanate; $\mathrm{TiO}_{2}$, titanium dioxide.

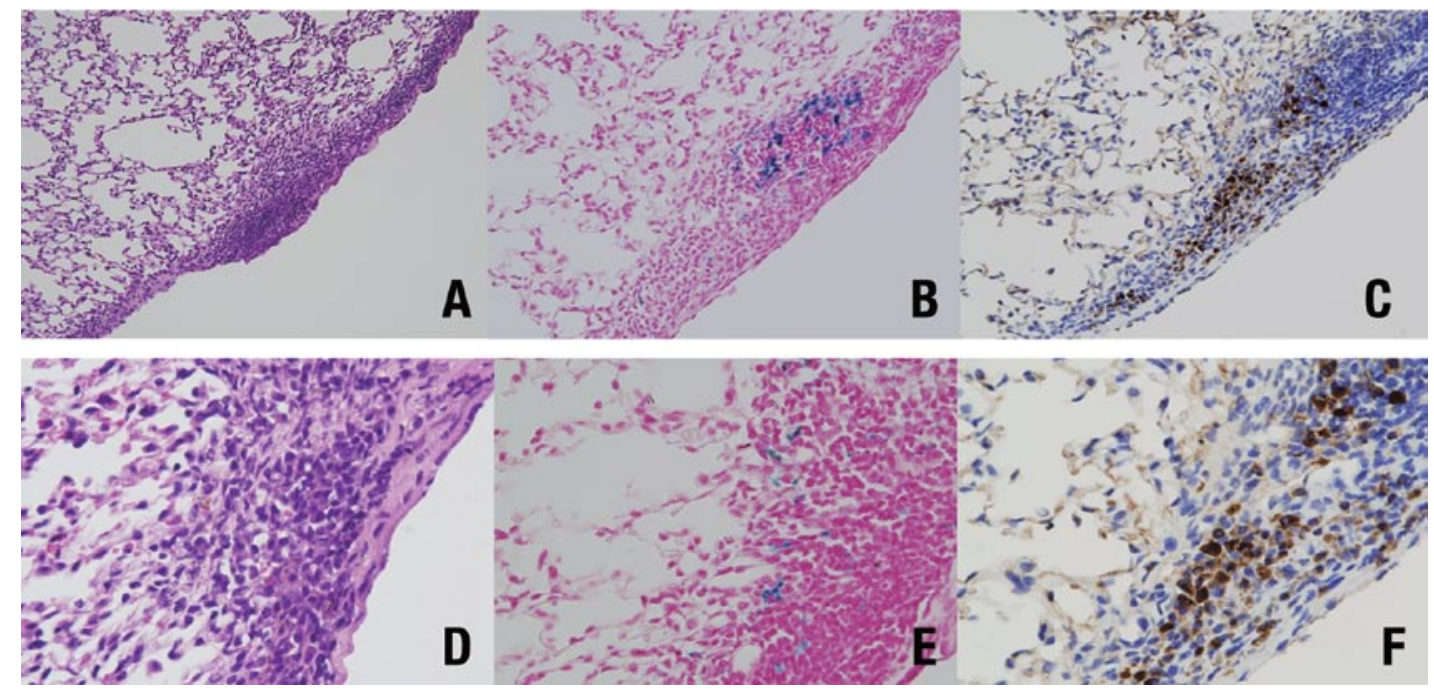

Figure 5. Lung findings for the TISMO-treated group (Group 1). (A and D) Pleural thickening. (B and E) Positive spots with Berlin blue staining. (C and F) Calretinin-positive cells. D, E and F are high magnifications of A, B and C, respectively.

were detected in the area of pleural thickening with TISMO fibers (Fig. 5A and D), but not in alveoli or in the other groups. Calretinin-positive cells were also observed in essentially the same lesions (Fig. 5C and F). In the liver, fatty degeneration was observed in 1 mouse in Groups 1 and 4, respectively. In the kidneys, tubular necrosis was noted in 1 mouse of Group 2. No other marked lesions were detected.

\section{Discussion}

In the present study, the particles, $\mathrm{TISMO}, \mathrm{TiO}_{2}$ nano and $\mathrm{TiO}_{2}$ micro, essentially consisted of the same material, i.e., titanium, but the shape (fiber or granular) was different. Only the fiber-shaped TISMO induced mesothelial cell reactions. To our knowledge, this is the first such study. Previously, fibrous particles greater than $1 \mu \mathrm{m}$ in length, with a length-towidth ratio $>10: 1$, were believed to have particular biological relevance for mesothelial risk (14). The TISMO used in our experiments, with dimensions mostly less than $50 \mu \mathrm{m}$ in length and less than $2 \mu \mathrm{m}$ in width, meets these criteria. Results of the present study show that it is not necessarily the chemical composition, but rather the physical characteristics of the material used that determined the reactions, including the severe adhesion and mesothelial cell accumulation.

The chemical formula of TISMO is $\mathrm{K}_{2} \mathrm{O} \cdot \mathrm{nTiO}_{2}$, although TISMO containing $\mathrm{K}_{2} \mathrm{O}$ is chemically different from $\mathrm{TiO}_{2}$. It is likely that the fomula containing $\mathrm{K}_{2} \mathrm{O}$ induced the mesothelial cell reactions. Therefore, the difference in the influence between the TISMO and $\mathrm{TiO}_{2}$ particles by focusing attention only on their shape may be relevant. Fewer mesothelial cell reactions induced both by $\mathrm{TiO}_{2}$ micro- and $\mathrm{TiO}_{2}$ nano-particles, which have the same chemical formula, were noted. It was thus proven that the mesothelial cell reactions are not influenced by particle size. Additionally, the TISMO results provide important reference and additional data concerning particle shape. To obtain detailed findings regarding the shape, future experiments should be performed with fiber-shaped and fine particles of identical chemical composition, such as milled fiber-shaped TISMO.

The Berlin blue staining used in this study showed iron accumulation around TISMO fibers in the thickened pleura, co-locating with immunostaining for calretinin, indicative of mesothelioma cells, although this was not noted in the pleura treated with the $\mathrm{TiO}_{2}$ nano- or micro-particles. DNA damage 
and apoptosis from iron-derived reactive oxygen species are regarded as important for malignant mesothelioma development (15-17). Furthermore, iron as a component of asbestos or as a consequence of asbestos-induced pathology is a significant candidate for underlying carcinogenic mechanisms, since iron overload is identified as being carcinogenic (18). Recently, intraperitoneal or intrascrotal application of multi-wall carbon nanotube (MWCNT) was reported to induce mesotheliomas $(19,20)$. Notably, TISMO contains no iron component, therefore the iron accumulation is likely to have derived from an endogenous source in the body. In our previous studies in which TISMO fibers administered by intratracheal instillation to F344 rats (4 mg per rat) were used, only mild inflammatory reactions were observed compared to quartz particles in the lungs after 28 days $(21,22)$. Results of other studies of TISMO administration by chronic inhalation also found limited inflammation in the lung $(23,24)$. However, inhaled fibers of TISMO may be able to penetrate the alveoli to the pleura, as demonstrated here in reverse, and this would elucidate the induction of pleural mesothelioma by inhalation of asbestos in humans.

The mesothelial cells in our reactive lesions showed only slight atypia, and it was difficult to make a diagnosis of malignant pleural mesothelioma. The experimental period of 21 weeks was determined based on a previous study (20) whose results indicated that the mortality rate due to mesothelioma increased approximately 130 days after intraperitoneal injection of MWCNT or crocidolite. However, the animals used in this study were not wild-type, but rather p53-heterozygous. Future studies in which the experiment is repeated using a longer time period need to be conducted.

No intergroup differences were observed in the incidence of lung adenoma. A/J female mice, a mouse strain which frequently develops lung tumors and is used commonly as a lung carcinogenesis model (25-27), were employed in the present study to assess the influence of particles or fibers on lung proliferative lesions. We assessd the influence on lung tumors without any chemicals, such as 4-(methylnitrosamino)1-(3-pyridyl)-1-butanone and tobacco-specific N-nitrosamine (28), to strongly initiate the effects. Subsequently, the present study may have had a short experimental time period. Exposure to asbestos which causes mesothelioma has a primarily occupational etiology, and the majority of cases are male $(29,30)$. When considering the strain used for malignant pleural mesothelioma, female mice were shown to be in conflict with the etiological evidence. Thus, male mice should be used for future experiments on mesothelioma.

In conclusion, the present study demonstrated that only fiber-shaped TISMO induced severe reactions of the mesothelium in the pleura, and these reactions involved iron accumulation derived from endogenous sources. The results indicate that the risk of mesothelial cell reaction does not depend on particle size, but may depend on the shape.

\section{Acknowledgements}

The authors thank Dr Malcolm A. Moore for the critical reading of the manuscript. This study was supported, in part, by Grants-in-Aid for Cancer Research from the Ministry of Health, Labour and Welfare of Japan.

\section{References}

1. Metintas S, Metintas M, Ucgun I and Oner U: Malignant mesothelioma due to environmental exposure to asbestos: follow-up of a Turkish cohort living in a rural area. Chest 122: 2224-2229, 2002.

2. Robinson BW, Musk AW and Lake RA: Malignant mesothelioma. Lancet 366: 397-408, 2005.

3. Murayama T, Takahashi K, Natori $\mathrm{Y}$ and Kurumatani $\mathrm{N}$ : Estimation of future mortality from pleural malignant mesothelioma in Japan based on an age-cohort model. Am J Ind Med 49: 1-7, 2006.

4. Price B and Ware A: Mesothelioma trends in the United States: An update based on surveillance, epidemiology, and end results program data for 1973 through 2003. Am J Epidemiol 159: 107-112, 2004.

5. Kim Y, Ton TV, DeAngelo AB, et al: Major carcinogenic pathways identified by gene expression analysis of peritoneal mesotheliomas following chemical treatment in F344 rats. Toxicol Appl Pharmacol 214: 144-151, 2006.

6. Kamstrup O, Ellehauge A, Collier CG and Davis JM: Carcinogenicity studies after intraperitoneal injection of two types of stone wool fibres in rats. Ann Occup Hyg 46: 135-142, 2002.

7. Krajnow A and Lao I: Assessment of carcinogenic effect of aluminosilicate ceramic fibers produced in Poland. Animal experiments. Med Pr 51: 19-27, 2000.

8. Crosby LM, Morgan KT, Gaskill B, Wolf DC and DeAngelo AB: Origin and distribution of potassium bromate-induced testicular and peritoneal mesotheliomas in rats. Toxicol Pathol 28: 253-266, 2000.

9. Jongsma J, van Montfort E, Vooijs M, et al: A conditional mouse model for malignant mesothelioma. Cancer Cell 13: 261-271, 2008.

10. Lardinois D, Jung FJ, Opitz I, et al: Intrapleural topical application of cisplatin with the surgical carrier vivostat increases the local drug concentration in an immune-competent rat model with malignant pleuromesothelioma. J Thorac Cardiovasc Surg 131: 697-703, 2006.

11. Moore AJ, Parker RJ and Wiggins J: Malignant mesothelioma. Orphanet J Rare Dis 3: 34, 2008.

12. Yokohira M, Hashimoto N, Yamakawa K, Saoo K, Kuno T and Imaida K: Lack of promoting effects from physical pulmonary collapse in a female $\mathrm{A} / \mathrm{J}$ mouse lung tumor initiated with 4-(methylnitrosamino)-1-(3-pyridyl)-1-butanone (NNK) with remarkable mesothelial cell reactions in the thoracic cavity by the polymer. Exp Toxicol Pathol (In press).

13. Shield PW and Koivurinne K: The value of calretinin and cytokeratin $5 / 6$ as markers for mesothelioma in cell block preparations of serous effusions. Cytopathology 19: 218-223, 2008.

14. Friedrichs KH and Molik B: Microscopic observations on some fibrous dust samples. Zentralbl Bakteriol Mikrobiol Hyg 181B: 216-225, 1985.

15. Kamp DW: Asbestos-induced lung diseases: An update. Transl Res 153: 143-152, 2009.

16. Jiang L, Nagai $\mathrm{H}$, Ohara $\mathrm{H}$, et al: Characteristics and modifying factors of asbestos-induced oxidative DNA damage. Cancer Sci 99: 2142-2151, 2008.

17. Aung W, Hasegawa S, Furukawa T and Saga T: Potential role of ferritin heavy chain in oxidative stress and apoptosis in human mesothelial and mesothelioma cells: implications for asbestosinduced oncogenesis. Carcinogenesis 28: 2047-2052, 2007.

18. Toyokuni S: Iron-induced carcinogenesis: the role of redox regulation. Free Radic Biol Med 20: 553-566, 1996.

19. Sakamoto Y, Nakae D, Fukumori N, et al: Induction of mesothelioma by a single intrascrotal administration of multi-wall carbon nanotube in intact male Fischer 344 rats. J Toxicol Sci 34: 65-76, 2009.

20. Takagi A, Hirose A, Nishimura T, et al: Induction of mesothelioma in $\mathrm{p} 53^{+/-}$mouse by intraperitoneal application of multi-wall carbon nanotube. J Toxicol Sci 33: 105-116, 2008.

21. Yokohira M, Takeuchi H, Yamakawa K, et al: Bioassay by intratracheal instillation for detection of lung toxicity due to fine particles in F344 male rats. Exp Toxicol Pathol 58: 211-221, 2007.

22. Yokohira M, Kuno T, Yamakawa K, et al: An intratracheal instillation bioassay system for detection of lung toxicity due to fine particles in F344 rats. J Toxicol Pathol 22: 1-10, 2009. 
23. Ikegami T, Tanaka A, Taniguchi $\mathrm{M}$, et al: Chronic inhalation toxicity and carcinogenicity study on potassium octatitanate fibers (TISMO) in rats. Inhal Toxicol 16: 291-310, 2004.

24. Ikegami T, Taniguchi M, Singer AW, et al: Inhalation toxicity of potassium octatitanate fibers (TISMO) in rats following 13 weeks of aerosol exposure. Inhal Toxicol 12: 415-438, 2000.

25. Gordon $\mathrm{T}$ and Bosland $\mathrm{M}$ : Strain-dependent differences in susceptibility to lung cancer in inbred mice exposed to mainstream cigarette smoke. Cancer Lett 275: 213-220, 2009.

26. Sharma S, Gao P and Steele VE: The chemopreventive efficacy of inhaled oltipraz particulates in the $\mathrm{b}[\mathrm{a}] \mathrm{p}$-induced $\mathrm{A} / \mathrm{J}$ mouse lung adenoma model. Carcinogenesis 27: 1721-1727, 2006.

27. Yokohira M, Takeuchi H, Saoo K, et al: Establishment of a bioassay model for lung cancer chemoprevention initiated with 4-(methylnitrosamino)-1-(3-pyridyl)-1-butanone (NNK) female A/J mice. Exp Toxicol Pathol 60: 469-473, 2008.
28. Takeuchi H, Saoo K, Yokohira M, et al: Pretreatment with 8-methoxypsoralen, a potent human CYP2a6 inhibitor, strongly inhibits lung tumorigenesis induced by 4 -(methylnitrosamino)1-(3-pyridyl)-1-butanone in female A/J mice. Cancer Res 63: 7581-7583, 2003.

29. Pukkala E, Martinsen JI, Lynge E, et al: Occupation and cancer - follow-up of 15 million people in five Nordic countries. Acta Oncol 48: 646-790, 2009.

30. Madkour MT, El Bokhary MS, Awad Allah HI, Awad AA and Mahmoud HF: Environmental exposure to asbestos and the exposure-response relationship with mesothelioma. East Mediterr Health J 15: 25-38, 2009. 